\title{
CANDESARTAN REVERSES MEMORY DEFICIT CAUSED BY COLCHICINE INDUCED CHOLINERGIC DYSFUNCTION AND OXIDATIVE STRESS
}

\author{
HIMANI AWASTHI ${ }^{*}$, H. H. SIDDIQUI ${ }^{2}$ \\ ${ }^{1}$ Amity University, Uttar Pradesh, Lucknow, India, ${ }^{2}$ Faculties of Pharmacy, Integral University, Lucknow, India \\ Email: himani1july@gmail.com
}

Received: 31 May 2017 Revised and Accepted: 22 Jul 2017

\section{ABSTRACT}

Objective: We sought to investigate the protective activity of candesartan against memory impairment, oxidative stress and cholinergic dysfunction induced by activation of the central renin-angiotensin system.

Methods: Male Swiss albino mice were divided into eight groups. Group 1 received vehicle (1.0\% w/v gum acacia), orally for $14 \mathrm{~d}$. Group 2 received intracerebrally (i. c.) artificial cerebrospinal fluid (aCSF, the vehicle of colchicine) and treated with vehicle for $14 \mathrm{~d}$. Group 3,4 and 5 injected with $i$. c. colchicine in the doses of $1 \mu \mathrm{g}, 2 \mu \mathrm{g}, 3 \mu \mathrm{g}$ respectively and treated with vehicle for $14 \mathrm{~d}$. Group 6 and 7 received $i . c$ colchicine $(3 \mu \mathrm{g})$ and treated with candesartan $(0.05$ and $0.1 \mathrm{mg} / \mathrm{kg}$ respectively) orally for $14 \mathrm{~d}$. Group 8 received i. $c$ colchicine $(3 \mu \mathrm{g})$ and treated with standard drug donepezil 5 $\mathrm{mg} / \mathrm{kg}(\mathrm{PO})$ for $14 \mathrm{~d}$.

Learning and memory behavior was assessed by using morris water maze. Biochemical parameters of oxidative stress and cholinergic function were estimated in the brain on day 18. Parameters of oxidative stress and cholinergic function were estimated after the completion of behavioral studies

Results: Treatment with a higher dose of colchicines ( $3 \mu \mathrm{g} / \mathrm{mice})$ caused memory deficit as shown by no significant decrease in escape latency time throughout all the sessions. Results of biochemical estimation showed a marked increase in malondialdehyde (MDA), nitrite level, reduced glutathione (GSH) level, cholinotoxic effect of colchicines has been correlated by marked decrease in acetyl cholinesterase (AChE) activity. Colchicine in a dose of $3 \mu \mathrm{g} / \mathrm{mice}$ has been validated. Pretreatment with candesartan in doses $0.05 \mathrm{and} 0.1 \mathrm{mg} / \mathrm{kg}$ reverses oxidative stress which can be measured by decreased MDA, nitrite level and increased GSH level. Increased AChE activity may imply protection of cholinergic neurons hence improvement in learning and memory behavior.

Conclusion: Preventive treatment with angiotensins receptor blocker, candesartan showed that memory impairment induced by colchicines may be mediated by alteration of central rennin angiotensins system and loss of cholinergic neurons. This study highlighted a number of clinical findings which support marked neuroprotection by blocked of the central AT1 receptor.

Keywords: Colchicine, Antioxidant activity, Neuroprotection

(c) 2017 The Authors. Published by Innovare Academic Sciences Pvt Ltd. This is an open access article under the CC BY license (http://creativecommons.org/licenses/by/4.0/) DOI: http://dx.doi.org/10.22159/ijpps.2017v9i9.20391

\section{INTRODUCTION}

The primary function of the renin-angiotensin system (RAS) is to maintain fluid homeostasis and regulate blood pressure [1]. Beyond the actions of peripheral RAS, an independent RAS exist in the brain [2]. The brain RAS has been suggested to contribute to the neurodegenerative disorders such as Alzheimer's disease or vascular dementia $[3,4]$. Several studies suggested the role of brain RAS in memory consolidation. Though, the participation of angiotensin II (AII) in this process is controversial. Some studies have demonstrated that acute administration of AII in the central nervous system improves the learning ability in rats. [5-7]. Delorenzi and Maldonado have reported, enhancing the effect of both exogenous AII and angiotensin IV (AIV) on memory consolidation on fear contextual memory in the crab, which can be reverted by nonspecific AII receptor antagonist saralasin $[8,9]$.

In our previous study AT1 receptor antagonist, candesartan improve learning and memory in streptozotocin model of dementia [10]. Another study report, that in step-down inhibitory avoidance task, AII blocked the formation of the long-term memory for a one-trial, when given into the CA1 region of the rat dorsal hippocampus [11]. AII type 1 receptor antagonist E4177 slightly improved the memory dysfunction observed in the aged Dahl salt-sensitive rat [12].

Colchicine induces neurofibrillary degeneration by binding to tubulin, the principal structural protein of microtubules and it inhibiting axoplasmic transport, and mitosis [13]. Its central administration can result in cell death associated with cognitive impairment [14]. In addition, it causes oxidative damage and generation of excessive free radical that can be positively correlated with the extent of cognitive impairment [15]. Colchicine causes loss of cholinergic neurons, destruction of cholinergic pathways, and a decrease in cholinergic turnover, induces hippocampal lesions resulting in learning and memory impairment, reduction in choline acetyltransferase [16], suggesting that it could be used as a suitable model for studying Alzheimer's disease.

Therefore ATI receptor blocker of RAS pathway may have an influence on learning and memory paradigm. The present study investigated the role of central ATI receptor in memory impairment, induced by intracerebral colchicines. The antihypertensive drug, ATI receptor blocker candesartan was used as an experimental tool. Further cholinergic dysfunction was estimated by acetyl cholinesterase assay and oxidative stress was measured by estimating the level of MDA, GSH, and nitrite.

\section{MATERIALS AND METHODS}

\section{Animals}

Adult male Swiss albino mice (25-30 g) were used. The animals were obtained from the Laboratory Animal Services Division of Central Drug Research Institute, Lucknow. The animals were kept in the polyacrylic cage $(22.5 \times 37.5 \mathrm{~cm})$ and maintained under standard housing conditions (room temperature $24-27^{\circ} \mathrm{C}$ and humidity $60-65 \%$ ) with a $12 \mathrm{~h}$ light and dark cycle. Food and water were available ad libitum but the food was not allowed from $1 \mathrm{~h}$ prior to the behavioural study. The experimental protocol was approved by the Institutional Animal Ethical Committee (No. 1213/ac/June 2008/ CPCSEA), and 
experiments were conducted in accordance with the CPSCEA guidelines on the use and care of experimental animals.

\section{Materials}

The biochemicals i. e. colchicine, chloral hydrate, sodium chloride $(\mathrm{NaCl})$, sodium nitrate $\left(\mathrm{NaNO}_{2}\right)$, sulphanilamide, naphthylamine diamine dihydrochloric, bovine serum albumin (BSA), acetylthiocholine iodide, 5, 5'-dithiobis (2-nitro-benzoic acid) (DTNB), 1, 1, 3, 3-tetraethoxypropane (TEP), glutathione (GSH) and 2thiobabituric acid (TBA) were purchased from Sigma-Aldrich, USA. Candesartan cilexetil was purchased from local market.

\section{Drug administration}

\section{Colchicines: intracerebral (i. c.) administration}

The animals were anesthetized with chloral hydrate $(300 \mathrm{mg} / \mathrm{kg}$, IP). A midline sagittal incision was made in the scalp. A 27 gauge hypodermic needle attached to a $100 \mu \mathrm{l}$ Hamilton syringe was inserted (2.5 $\mathrm{mm}$ depth) perpendicularly through the skull into the brain. Colchicine $(1,2$ and $3 \mu \mathrm{g} / 10 \mu \mathrm{l})$, dissolved in freshly prepared artificial CSF (aCSF), was administered slowly in a volume of $10 \mu \mathrm{l}$ by intracerebral (i. c.) route. The site of injection was $2 \mathrm{~mm}$ from either side of the midline on a line drawn through the anterior base of the ears. The syringe was left in the place for a further 2 min for proper diffusion of colchicine [17].

\section{Administration of candesartan}

For oral administration, candesartan was suspended in $1.0 \% \mathrm{w} / \mathrm{v}$ gum acacia immediately before administration in a constant volume of $10 \mathrm{ml} / \mathrm{kg}$ body weight. To study the effect of candesartan in morris water maze, it was administered at doses of 0.05 and 0.1 $\mathrm{mg} / \mathrm{kg}$ starting from the first dose of colchicine for $14 \mathrm{~d}$. Candesartan was administered orally one $\mathrm{hr}$ before colchicine administration on the $1^{\text {st }}$ day [10].

\section{Administration of acetylcholinesterase inhibitor in mice}

Donepezil was administered at a dose of $5 \mathrm{mg} / \mathrm{kg}$ for $14 \mathrm{~d}$. It was administered as $1 \%$ aqueous suspension with gum acacia [18], $1 \mathrm{hr}$ before colchicine administration on day 1 .

\section{Experimental protocol}

Animals were randomly divided into eight groups of 5 animals each.

Group 1: Control mice treated with a vehicle of candesartan $(1.0 \%$ $\mathrm{w} / \mathrm{v}$ gum acacia) for $14 \mathrm{~d}$.

Group 2: Mice injected with intracerebrally (i. c) artificial cerebrospinal fluid (aCSF, the vehicle of colchicine) and treated with vehicle for $14 \mathrm{~d}$.

Group 3: Mice injected with i. c. colchicine $(1 \mu \mathrm{g})$ and treated with vehicle for $14 \mathrm{~d}$

Group 4: Mice injected with i. c. colchicine $(2 \mu \mathrm{g})$ and treated with vehicle for $14 \mathrm{~d}$.

Group 5: Mice injected with i. c. colchicine ( $3 \mu \mathrm{g})$ and treated with vehicle for $14 \mathrm{~d}$

Group 6: Mice injected with i. c. colchicine $(3 \mu \mathrm{g})$ and treated with candesartan $0.05 \mathrm{mg} / \mathrm{kg}(\mathrm{PO})$ for $14 \mathrm{~d}$

Group 7: Mice injected with i.c. colchicine $(3 \mu \mathrm{g})$ and treated with candesartan $0.1 \mathrm{mg} / \mathrm{kg}$ (PO) for $14 \mathrm{~d}$

Group 8: Mice injected with i. c. colchicine $(3 \mu \mathrm{g})$ and treated with donepezil $5 \mathrm{mg} / \mathrm{kg}$ (PO) for $14 \mathrm{~d}$

Animals from Group 1, 2 and 5-8 were sacrificed on day 18 and tissues were taken for biochemical studies

\section{Evaluation of spatial memory by morris water maze test}

The Morris water maze consisted of a large circular black pool of $120 \mathrm{~cm}$ diameter, $50 \mathrm{~cm}$ height, filled to a depth of $30 \mathrm{~cm}$ with water at $26 \pm 2{ }^{\circ} \mathrm{C}$. A black colored round platform of $8 \mathrm{~cm}$ diameter was placed $1 \mathrm{~cm}$ below the surface of the water in a constant position.
The water was colored with non-toxic black dye to hide the location of the submerged platform. The pool was divided into four hypothetical quadrants.

On the $14^{\text {th }}$ day from colchicine injection, spatial learning and memory of animals were tested in Morris water maze. Trials were given for 5 consecutive days in order to train mice in the Morris water maze. The mice were given a maximum time of 60 s (cut-off time) to find the hidden platform and were allowed to stay on it for $30 \mathrm{~s}$. The experimenter put the mice on platform himself that failed to locate the platform. The animals were given a daily session of 3 trials per day. Latency time to reach the platform was recorded in each trial. Mean latency time of all three trials is shown in the results. A significant decrease in latency time from that of $1^{\text {st }}$ session was considered as a successful learning [18].

\section{Spontaneous locomotor activity}

Locomotor activity was tested one hr before water maze trial on $14^{\text {th }}$ day after colchicine administration. After a period of $15 \mathrm{~min}$ for acclimatization in Optovarimex activity meter, each animal was observed for $10 \mathrm{~min}$ taking readings every $2 \mathrm{~min}$. Results were expressed as mean counts/2 min.

\section{Estimation of biochemical parameters}

AChE and biochemical parameters of oxidative stress, MDA and GSH, and Nitrite were measured in the brain on the $18^{\text {th }}$ day after colchicine Injection.

\section{Brain tissue preparation}

The mice were decapitated under ether anesthesia. The skull was cut open and the brain was exposed from its dorsal side. The whole brain was quickly removed and cleaned with chilled normal saline on the ice. A $10 \%(\mathrm{w} / \mathrm{v})$ homogenate of brain samples in $0.03 \mathrm{M}$ sodium phosphate buffer ( $\mathrm{pH}$ 7.4) was prepared.

\section{Estimation of oxidative stress markers}

Brain tissue homogenate $(10 \% \mathrm{w} / \mathrm{v}$ in $0.03 \mathrm{M}$ sodium phosphate buffer, $\mathrm{pH}$ 7.4) was prepared by using homogenizer at a speed of 9,500 rpm.

\section{Measurement of MDA}

MDA, a marker of lipid peroxidation, was estimated in the brain tissues, according to the method of Colado et al. [19]. After homogenization, tissue homogenate was mixed with $30 \%$ trichloroacetic acid (TCA), $5 \mathrm{~N} \mathrm{HCl}$ followed by the addition of $2 \%$ thiobarbituric acid (TBA) in $0.5 \mathrm{~N} \mathrm{NaOH}$. The mixture was heated for $15 \mathrm{~min}$ at $90{ }^{\circ} \mathrm{C}$ and centrifuged at $12,000 \mathrm{~g}$ for $10 \mathrm{~min}$. The pink color of the supernatant was measured at $532 \mathrm{~nm}$ on UV-visible spectrophotometer. MDA concentration was calculated by using standard curve prepared with Tetra Ethoxy propane and expressed as $\mathrm{nmol} / \mathrm{mg}$ protein.

\section{Measurement of GSH}

GSH was determined by its reaction with 5, 5'-dithiobis (2nitrobenzoic acid) (DTNB) to yield a yellow chromophore which was measured spectrophotometrically. The brain homogenate was mixed with an equal amount of $10 \%$ TCA and centrifuged at 2,000 g for 10 $\min$ at $4{ }^{\circ} \mathrm{C}$. The supernatant was used for GSH estimation. The processed tissue sample was mixed with phosphate buffer of $\mathrm{pH} 8.4$ and DTNB and the mixture was shaken vigorously on vortex. The absorbance was read at $412 \mathrm{~nm}$ using UV-visible spectrophotometer. Standard curve was prepared with reduced glutathione and GSH concentration was expressed as $\mu \mathrm{g} / \mathrm{mg}$ protein [20].

\section{Nitrite estimation}

Nitrite was estimated in the mice brain using the Greiss reagent and served as an indicator of nitric oxide (NO) production [21]. An equal volume of Greiss reagent (1:1 solution of $1 \%$ sulphanilamide in $5 \%$ Ortho-phosphoric acid and $0.1 \%$ naphthylamine diamine dihydrochloric acid in water) and processed tissue sample was mixed and absorbance was measured at $542 \mathrm{~nm}$ using a UV-visible spectrophotometer. Nitrite concentration was calculated using a standard curve for sodium nitrite and expressed in $\mu \mathrm{g} / \mathrm{mg}$ protein. 


\section{Sample preparation and assay of AChE activity}

The brain homogenate in the volume of $500 \mu \mathrm{l}$ was mixed with $1 \%$ Triton X-100 (1\% w/v in $0.03 \mathrm{M}$ sodium phosphate buffer, $\mathrm{pH}-7)$ and centrifuged at $100,000 \mathrm{~g}$ at $4^{\circ} \mathrm{C}$ in a Ultracentrifuge for $60 \mathrm{~min}$. The supernatant was collected and stored at $4^{\circ} \mathrm{C}$ for acetylcholinesterase estimation by Ellman's method [22].

The kinetic profile of enzyme activity was measured by UVvisible spectrophotometer at $412 \mathrm{~nm}$ with an interval of $15 \mathrm{~s}$. One unit of acetylcholinesterase activity was defined as the number of micromoles of acetylthiocholine iodide hydrolyzed per minute per milligram of protein. The specific activity of acetyl cholinesterase is expressed in $\mu \mathrm{moles} / \mathrm{min} / \mathrm{mg}$ protein.

\section{Protein estimation}

Protein was measured in all brain samples for nitrite, GSH and MDA by the method of Lowry et al. (1951) and protein for acetylcholine esterase activity by the method of Wang and Smith (1975) [23, 24]. Bovine serum albumin (BSA) $(1 \mathrm{mg} / \mathrm{ml})$ was used as standard and measured in the range of $0.01-0.1 \mathrm{mg} / \mathrm{ml}$.

\section{Statistical analysis}

The results are expressed as mean \pm SEM Statistical analysis of Morris water maze data was done by one-way analysis of variance (ANOVA) Biochemical values were analyzed by ANOVA followed by Tukey's test.

\section{RESULTS}

Effect of candesartan on colchicine induced memory impairment in mice

As shown in fig. 1 control $[\mathrm{F}(4,20)=66.48, \mathrm{P}<0.01]$ and $\operatorname{aCSF}[\mathrm{F}(4$, $25)=38.3, P<0.01]$ injected mice showed significant decrease in escape latency time (ELT) from session three onward indicating spatial learning. To induce memory impairment, colchicine was administered intracerebrally at 1,2 and $3 \mu \mathrm{g} /$ mice dose and memory function was evaluated $14 \mathrm{~d}$ after colchicine administration. Colchicine at $1 \mu \mathrm{g}$ dose $[\mathrm{F}(4,20)=10.63, \mathrm{P}<0.05]$ showed a significant decrease in ELT at session 4 and 5 . Colchicine at $2 \mu \mathrm{g}$ dose $[\mathrm{F}(4,20)=3.33$, $\mathrm{P}<0.05]$ showed significant decrease in ELT at session 5 while the dose of $3 \mu \mathrm{g}[\mathrm{F}(4,20)=0.93, \mathrm{P}>0.05]$ caused memory deficit as shown by no significant decrease in ELT throughout all the sessions. Colchicine in dose of $3 \mu \mathrm{g} /$ mice has been validated.

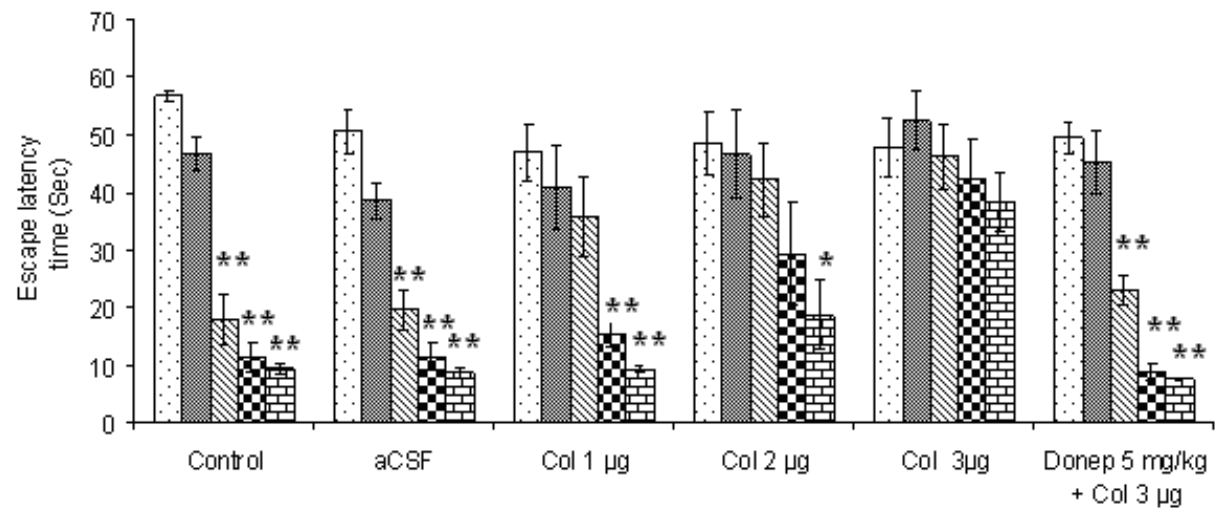

Fig. 1: Effect of various doses of colchicines in morris water maze trial, results are expressed as mean latency time (sec) \pm Standard error. * Significant difference $\left({ }^{* *} \mathrm{P}<0.01\right.$ and $\left.{ }^{*} \mathrm{P}<0.05\right)$ in latency time in comparison to session $1(\mathrm{n}=5)$

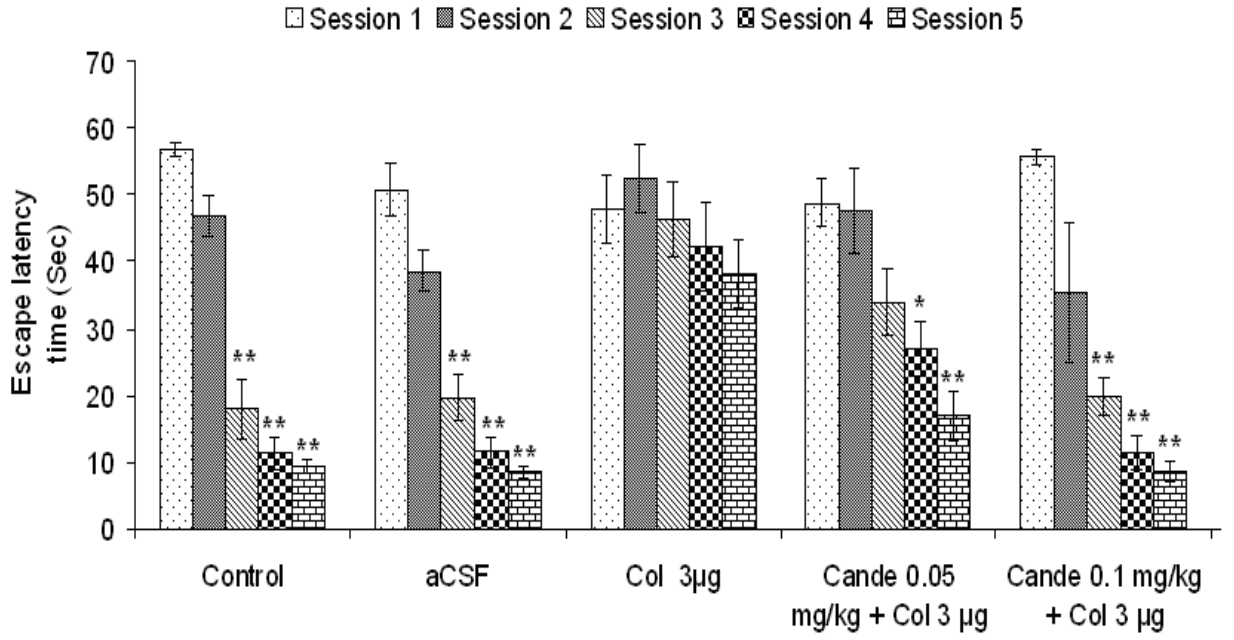

Fig. 2: Effect of candesartan on colchicine induced memory impairment in mice, results are expressed as mean latency time (sec) \pm Standard error. * Significant difference $(* * P<0.01$ and $* P<0.05)$ in latency time in comparison to session 1 . ( $n=5)$

AT1 receptor blocker candesartan was used to study the role of AII in colchicine induced memory impairment. As shown in fig. 2, colchicines induced memory impairment was reversed by candesartan in dose dependent manner.
Candesartan $0.05 \mathrm{mg} / \mathrm{kg}[\mathrm{F}(4,20)=8.5, \mathrm{P}<0.01]$ treated mice showed significant decrease in ELT from session 4 onward whereas higher dose $[\mathrm{F}(4,20)=15.09, \mathrm{P}<0.01]$ decreased ELT from session 3 onward. 
Biochemical estimations

Effect of candesartan on MDA level in colchicine induced memory deficit mice brain

Colchicine caused a significant increase in MDA level as compared with control and aCSF groups $[\mathrm{F}(2,12)=33.30, \mathrm{P}<0.01]$. This increase in MDA was attenuated by candesartan treatment $[\mathrm{F}(2,12)=46.24$ $\mathrm{P}<0.01]$. However, administration of $\operatorname{aCSF}(i . c$.) had no significant $(\mathrm{P}>0.05$ ) effect on MDA level as compared to control (fig. 3 ).
Effect of candesartan on GSH level in colchicine induced memory deficit mice brain

A significant fall in the levels of GSH was observed in the colchicine group as compared to the control and aCSF treated groups $[\mathrm{F}(2,12)=24.86, \mathrm{P}<0.01]$. Treatment with candesartan dose dependently prevented the decrease in GSH levels in the brain of colchicine-injected mice $[\mathrm{F}(2,12)=15.49, \mathrm{P}<0.01]$ (fig. 4).

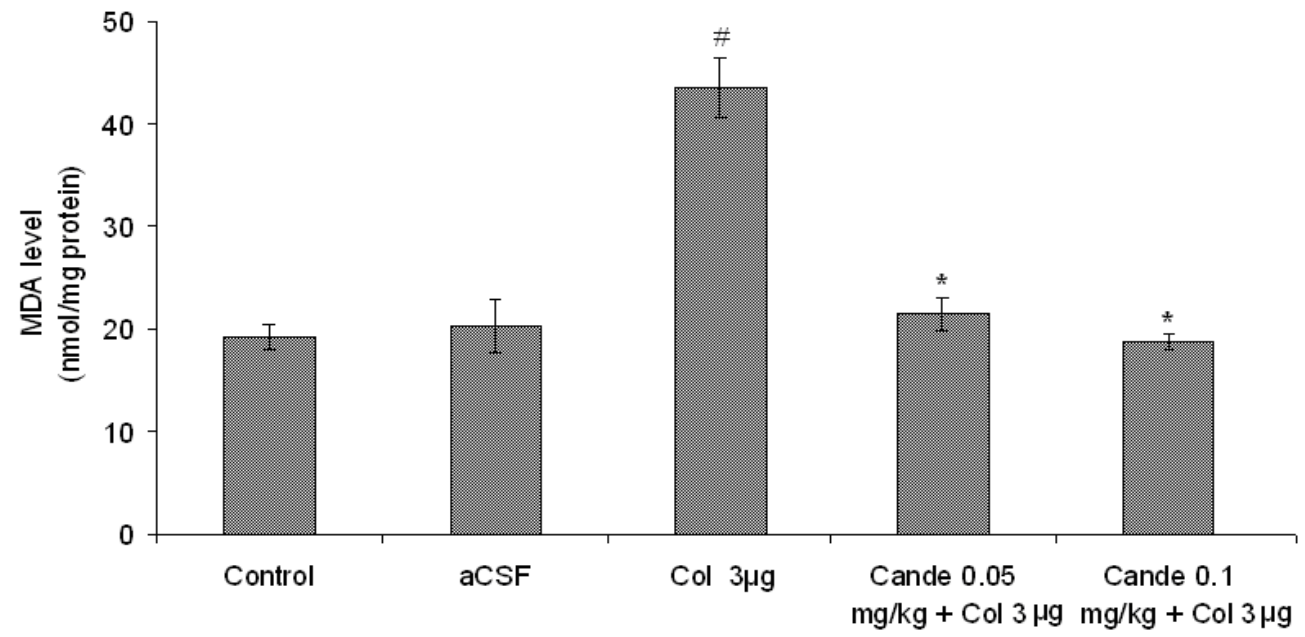

Fig. 3: Effect of candesartan on Malondialdehyde (nmol/mg protein) level in mice brain, results were expressed as a mean \pm Standard error and analyzed by one way ANOVA followed by Tukey's test. \#Significant difference (\#P<0.01) vs control and aCSF group; *Significant difference $(* P<0.01)$ vs colchicine group $(n=5)$

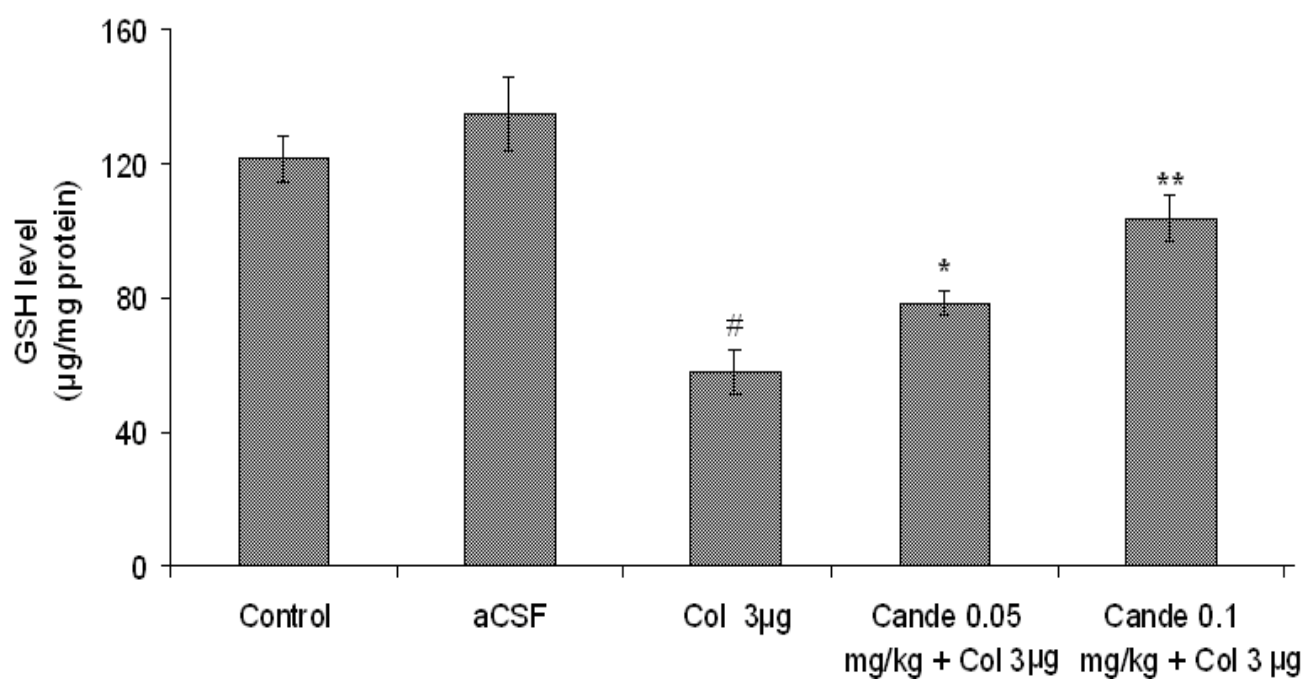

Fig. 4: Effect of candesartan on GSH ( $\mu \mathrm{g} / \mathrm{mg}$ protein) level in mice brain, results were expressed as a mean \pm Standard error and analyzed by one way ANOVA followed by Tukey's test. \#Significant difference $(\# P<0.01)$ vs control and aCSF group; *Significant difference $\left({ }^{*}<<0.05\right.$ and $\left.{ }^{* *} \mathbf{P}<0.01\right)$ vs colchicine group. $(\mathbf{n}=5)$

Effect of candesartan on nitrate level in colchicine induced memory deficit mice brain

A significant rise in nitrite level was observed in the brain of colchicine treated mice in comparison to control and aCSF groups $[\mathrm{F}(2,12)=13.57, \mathrm{P}<0.01]$. Candesartan treatment significantly inhibited this increase in nitrite levels in colchicine treated mice $[\mathrm{F}(2,12)=17.65, \mathrm{P}<0.01]$ (fig. 5).
Effect of candesartan on AChE activity in colchicine induced memory deficit mice brain

AChE activity was significantly decreased in the colchicine treated mice brain when compared with control and aCSF groups $[\mathrm{F}(2,12)=11.11, \mathrm{P}<0.01]$. Chronic candesartan treatment significantly $[\mathrm{F}(2,15)=6.38, \mathrm{P}<0.05]$ prevented this decrease in AChE activity (fig. 6) 


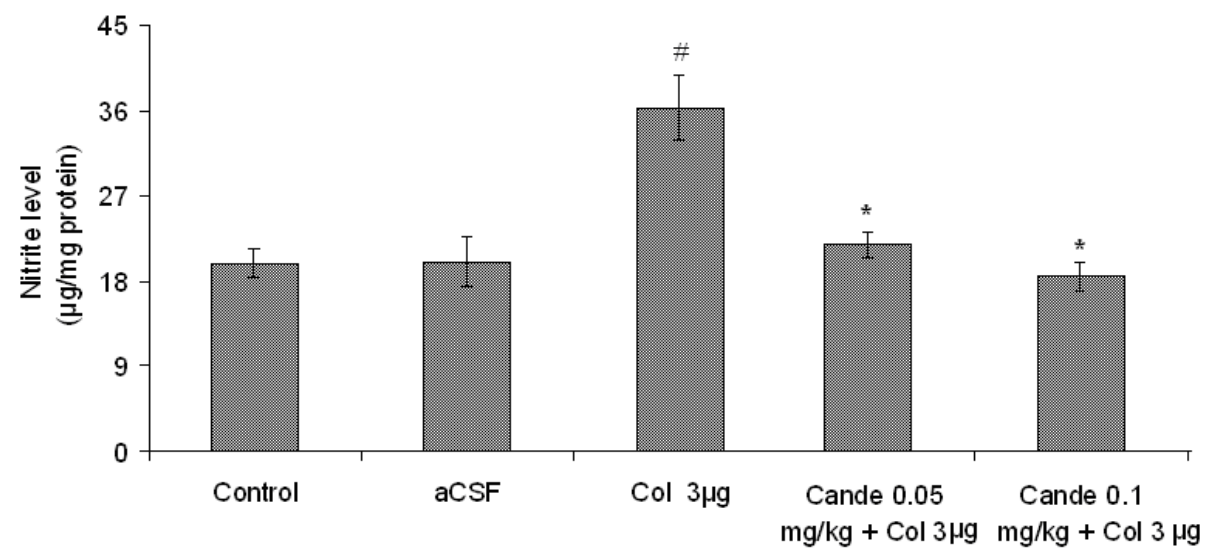

Fig. 5: Effect of candesartan on nitrite $(\mu \mathrm{g} / \mathrm{mg}$ protein) level in mice brain, results were expressed as mean \pm Standard error and analyzed by one way ANOVA followed by Tukey's test. \#Significant difference $(\# \mathrm{P}<0.01)$ vs control and aCSF group; *Significant difference $(* P<0.01)$ vs colchicine group $(n=5)$

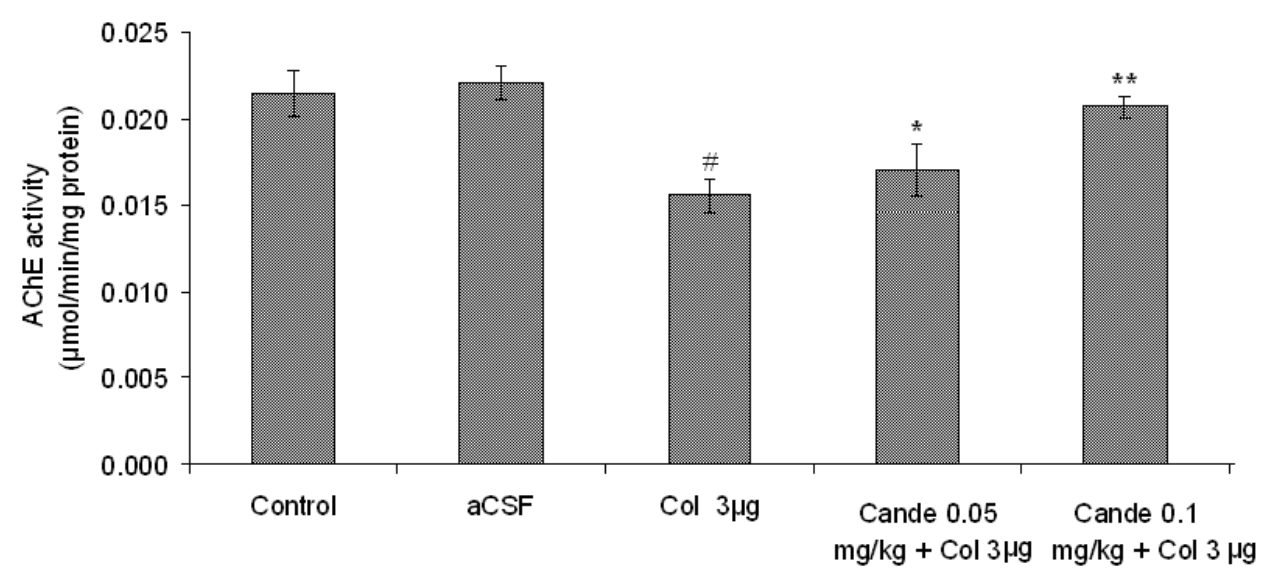

Fig. 6: Effect of candesartan on AChE activity $(\mu \mathrm{g} / \mathrm{min} / \mathrm{mg}$ protein) in mice brain. Results were expressed as mean \pm Standard error \#Significant difference $(\# \mathbf{P}<0.01)$ vs control and aCSF group; ${ }^{* S i g n i f i c a n t ~ d i f f e r e n c e ~}(* \mathrm{P}<0.01)$ vs colchicine group $(\mathrm{n}=5)$

\section{DISCUSSION}

This study investigated the role of central RAS in memory function and its relation with changes in biochemical markers of cholinergic function and oxidative stress in intra-cerebral (i. c.) colchicine induced a model of memory deficit in mice. The present study showed that AT1 receptor has the crucial role in preventing memory deficit induced by i. c. colchicines. It has been reported that central administration of colchicine induces memory impairment in rodents by causing cholinergic neurodegeneration and oxidative stress [25]. In the present study $i$. $c$. administration of colchicine at a dose of 3 $\mu \mathrm{g} /$ mice induced spatial memory impairment as indicated by no significant reduction in escape latency time in Morris water maze test. However, a lower dose of colchicine failed to induce memory deficit. Therefore, further studies were carried out by using colchicine at $3 \mu \mathrm{g} / \mathrm{mice}$ dose.

This finding is in agreement with previous studies reporting impairment in memory following colchicine administration [26]. Further, the colchicine induced memory impairment model was validated by clinically used antidementic-anticholinesterase drug donepezil. Preventive treatment with donepezil for $14 \mathrm{~d}$ ameliorated colchicine induced memory impairment in mice. Involvement of central RAS in colchicine induced memory impairment was studied by using AT1 receptor blocker candesartan. Candesartan was administered chronically for $14 \mathrm{~d}$ in colchicine injected mice and memory function was tested by Morris water maze. Candesartan prevented colchicine induced dementia in mice implicating the role of the central AT1 receptor in memory function. Locomotor activity of experimental animals was not altered. We found elevated nitrosative (increased nitrite level), oxidative stress (decreased GSH and increased MDA) and decreased AChE level in colchicine treated mice brain which was reversed by preventive treatment of ATI receptor blocker candesartan.

\section{CONCLUSION}

The treatment with candesartan alleviates colchicine induced memory impairment in mice. Intra-cerebral injection of colchicines leads to memory impairment by micro tubular dysfunction which may lead to loss of cholinergic neuron further oxidation of neuronal cell is also another implication of colchicines which again leads to memory deficit.

Candesartan, an ATI receptor blocker reverses memory deficit caused by colchicines. Which support the hypothesis of reversal of cholinergic dysfunction and oxidative stress by treatment of candesartan.

This study supported a number of clinical findings that central AT1 receptor blockade could be neuroprotective.

\section{CONTRIBUTION OF AUTHORS}

Awasthi $\mathrm{H}$ researched and Siddiqui $\mathrm{HH}$ provided guidance, critical review, revision and approved the final version of this study.

\section{CONFLICT OF INTERESTS}

All authors have none to declare 


\section{REFERENCES}

1. Petrillo Jr EW, Ondetti MA. Angiotensin-converting enzyme inhibitors: medicinal chemistry and biological actions. Med Res Rev 1982;2:1-41.

2. Sirrett NE, McLean AS, Bray JJ, Hubbard JL. Distribution of angiotensin II receptors in rat brain. Brain Res 1977;122:299-312.

3. Egemen Savaskan. The role of the brain renin-angiotensin system in neurodegenerative disorders. Curr Alzheimer Res 2005;2:29-35.

4. Deb D, Nayak V, Bairy L, Kurady, Rao M. Ameliorative effects of angiotensin receptor blockers against scopolamine-induced memory impairment in rats. Asian J Pharm Clin Res 2016;9:335-41.

5. Braszko JJ, Kulakowska A, Wisniewski K. Angiotensin II and its 3-7 fragment improves recognition but not spatial memory in rats. Brain Res Bull 1995;37:627-31.

6. Wright JW, Harding JW. Brain angiotensin receptor subtypes in the control of physiological and behavioral responses. Neurosci Biobehav Rev 1994;18:21-53.

7. Lind R, Swanson LW, Ganten D. Organization of angiotensin II immunoreactive cells and fibres in the rat central nervous system. Neuroendocrinology 1985;40:2-24.

8. Delorenzi A, Maldonado H. Memory enhancement by the angiotensinergic system in the crab chasmagnathus is mediated by endogenous angiotensin II. Neurosci Lett 1999;266:1-4.

9. Delorenzi A, Pedreira ME, Romano A, Silvia I, Garcia, Carlos J, et al. Angiotensin II enhances long-term memory in the crab chasmagnathus. Brain Res Bull 1996;41:211-20.

10. Tota S, Kamat PK, Awasthi H, Singh N, Raghubir R, Nath C, et al. Candesartan improves memory decline in mice: involvement of AT1 receptors in memory deficit induced by intracerebral streptozotocin. Behav Brain Res 2009;16:235-40.

11. Daniel S, Kerr, Lia R, Bevilaqua M, Juliana S, Bonini J, et al. Angiotensin II blocks memory consolidation through an AT2 receptor-dependent mechanism. Psychopharmacology 2005; 179:529-35.

12. Nobuhito Hirawa, Yoshio Uehara, Yukari Kawabata, Ikeda T. Longterm inhibition of renin-angiotensin system sustains memory function in aged dahl rats, Hypertension 1999;34:496-502.

13. Newell DW, Hsu SS, Papermaster V, Malouf AT. Colchicine is selectively neurotoxic to dentate granule cells in organotypic cultures of rat hippocampus. Neurotoxicology 1993;14:375-80.

14. Tilson HA, McLamb RL, Shaw S, Rogers BC, Pediaditakis P, Cook L. Radial-arm maze deficits produced by colchicine administered into the area of the nucleus basalis are ameliorated by cholinergic agents. Brain Res 1988;438:83-94.
15. Kumar MHV, Gupta YK. Intracerebroventricular administration of colchicine produces cognitive impairment associated with oxidative stress in rats. Pharmacol Biochem Behavior 2002;73:565-71.

16. Kolasa, Jope K, Bairdand RS, Gai MS, Johnson VW. Alterations of choline acetyltransferase, phosphoinositide. hydrolysis, and cytoskeletal proteins in rat brain in response to colchicine administration. Exp Brain Res 1992;89:496-500.

17. Saxena G, Singh SP, Agrawal R, Nath C. Effect of donepezil and tacrine on oxidative stress in an intracerebral streptozotocininduced model of dementia in mice. Eur J Pharmacol 2008;10:283-9.

18. Maralla S, Reddy S. Effect of aqueous extract of ginger on acetylcholine in the brain and its possible role in learning and memory during ethanol withdrawal. Asian J Pharm Clin Res 2017;7:192-8.

19. Colado MI, O'Shea E, Granados R, Misra A, Murray TK, Green AR. A study of the neurotoxic effect of MDMA ('ecstasy') on 5HT neurones in the brains of mothers and neonates following administration of the drug during pregnancy. Br J Pharmacol 1997;121:827-33.

20. Ellman GL. Tissue sulfhydryl groups. Arch Biochem Biophys 1959;82:70-7.

21. Green LC, Wagner DA, Glogowski J, Skipper PL, Wishnok JS, Tannenbaum SR. Analysis of nitrate, nitrite, and [15N]nitrate in biological fluids. Anal Biochem 1982;126:131-8.

22. Ellman GL, Courtney KD, Andres V Jr, Feather-Stone RM. A new and rapid colorimetric determination of acetylcholinesterase activity. Biochem Pharmacol 1961; 7:88-95.

23. Lowry $\mathrm{OH}$, Rosebrough NJ, Farr AL, Randall RJ. Protein measurement with the folin phenol reagent. J Biol Chem 1951;193:265-75.

24. Wang C, Smith RL. Lowry determination of protein in the presence of triton X-100. Anal Biochem 1975;63:414-7.

25. Fogari R, Mugellini A, Zoppi A, Marasi G, Pasotti C, Poletti L, et al. Effects of valsartan compared with enalapril on blood pressure and cognitive function in elderly patients with essential hypertension. Eur J Clin Pharmacol 2004;59:863-8.

26. Awasthi H, Kaushal D, Siddiqui HH. Chronic inhibition of central angiotensin-converting enzyme ameliorates colchicine-induced memory impairment in mice. Sci Pharm 2012;80:647-62.

\section{How to cite this article}

- $\quad$ Himani Awasthi, HH Siddiqui. Candesartan reverses memory deficit caused by colchicine induced cholinergic dysfunction and oxidative stress. Int J Pharm Pharm Sci 2017;9(9):184-189. 